\title{
Geliat dan Keterpengaruhan Tafsir Alquran dalam Dakwah di Malaysia
}

\author{
Zakirman $^{1}$; Shafwatul Bary ${ }^{2}$ \\ ${ }^{1}$ Fakultas Dakwah dan Ilmu Komunikasi Universitas Islam Negeri Imam Bonjol Padang; \\ zakirman@uinib.ac.id \\ 2Universitas Islam Negeri Sunan Kalijaga Yogyakarta; shafwatulbary1995@gmail.com
}

\begin{abstract}
The process of interpreting the Quran continues to evolve from Arabic to all corners of the world. Among other things, Malaysia. The Qur'anic interpretation in Malaysia dates back to the 17th century through oral para da'i. While the tradition of writing the Qur'anic interpretations only appeared in the 20th century. And as one way of transmitting Islamic values, the interpretation of the Quran in Malaysia took place in the da'i's preaching and under the influence of the previous interpreters. Recorded Abdurrauf as-Sinkily, Muhammad Abduh and Rasyid Ridha, and al-Maraghi were the most influential figures in interpreting the Quran and Islamic studies in Malaysia. This article will look at how the Qur'anic interpretations travel according to the way of transmission by the da'i, and how the influence of each character changes the order of interpretation in Malaysia. As a result, the process of interpreting the Quran in Malaysia was identified as growing through the hands of the da'is who were exposed to the ideology of their teachers, as well as the previous interpreters.
\end{abstract}

Keyword: Quran; interpretation; preacher; dakwah; influence

\begin{abstract}
ABSTRAK
Proses penafsiran Alquran terus berkembang sejak dari Arab sampai ke seluruh penjuru dunia. Di antaranya, Malaysia. Penafsiran Alquran di Malaysia bermula sejak abad ke 17 melalui oral para da'i. Sedangkan tradisi tulis menulis tafsir Alquran baru muncul pada abad 20. Dan sebagai salah satu cara transmisi nilai-nilai keislaman, penafsiran Alquran di Malaysia berlangsung dalam dakwah para da'i dan di bawah pengaruh para tokoh tafsir sebelumnya. Tercatat Abdurrauf as-Sinkily, Muhammad Abduh dan Rasyid Ridha, dan al-Maraghi adalah tokoh-tokoh yang paling mempengaruhi penafsiran Alquran dan studi Islam di Malaysia. Artikel ini akan melihat bagaimana perjalanan tafsir Alquran sesuai cara transmisinya oleh para da'i, dan bagaimana pengaruh masing-masing tokoh merubah tatanan studi tafsir di Malaysia. Hasilnya, proses penafsiran Alquran di Malaysia teridentifikasi tumbuh melalui tangan-tangan para da'i yang terpapar ideologi gurunya, sekaligus para mufassir sebelumnya.
\end{abstract}

Kata Kunci : Alquran; tafsir; da'l; dakwah; pengaruh 


\section{PENDAHULUAN}

Al-Qur'an shalih li kulli zaman wa makan, adagium filosofis ini menunjukkan bahwa Al-Qur'an itu selalu shalih dan berjalan selaras menembus batas-batas waktu dan tempat-tempat yang berbeda. Sehingga Al-Qur'an itu sendiri harus dipahami manusia khususnya yang beragama Islam-dimanapun dan kapanpun agar keshalihan Al-Qur'an tersebut benarbenar terwujud.

Al-Qur'an tidak hanya dibaca di berbagai tempat, namun juga dipahami demi sampainya pesan-pesan tuhan yang terkandung di dalamnya. Wilfred Cantwel Smith menegaskan bahwa Al-Qur'an adalah kitab suci istimewa yang paling banyak dibaca di dunia sejak diturunkan belasan abad yang lalu hingga sekarang. (Wilfred C. Smith,2005: 115-144). Senada dengan Smith, Huston Smith juga mengatakan bahwa Al-Qur'an adalah kitab suci yang paling banyak dihafal dan paling besar pengaruhnya terhadap mereka yang membacanya. Lihat Huston Smith, (2011:267) Agama-agama Manusia, Allah sebagai author dari AlQur'an, menurunkannya kepada Nabi Muhammad (w. 632M) melalui malaikat Jibril. Dan karena -salah satu alasannyaNabi Muhammad tersebut adalah seorang Arabiy (orang Arab), maka Al-Qur'an pun turun dengan berbahasa Arab abad ke VII, abad di mana periode hidupnya Nabi Muhammad. Al-Qur'an yang turun berbahasa Arab, tentunya akan mudah dipahami secara langsung oleh orang Arab itu sendiri, dan orang-orang yang mengerti bahasa Arabnya Al-Qur'an. Baik melalui penafsiran-penafsiran yang telah dilakukan sejak masa Nabi Muhammad masih hidup, maupun melalui beberapa karya tafsir dari para mufassir periode awal sampai sekarang.

Penafsiran Al-Qur'an itu sendiri terus berkembang menembus ruang dan waktu. Tidak hanya di Arab, namun juga di seluruh penjuru dunia, termasuk wilayah Asia Tenggara. Pada artikel ini penulis akan concern melihat bagaimana proses perkembangan tafsir Alquran melalui oral para da'i dan paparan ideologi siapa yang mempengaruhi penafsirannya saat mendakwahkan Alquran di salah satu negara Asia Tenggara; Malaysia. Melalui artikel ini kita akan melihat bagaimana transimisi nilai-nilai Al-Qur'an di Malaysia yang disalurkan para da'i. Pembahasannya akan ditekankan pada geliat, corak, karakteristik, dan keterpengaruhan tafsir Alqurannya da'i di sana.

\section{Geliat Tafsir Al-Qur'an di Malaysia}

Secara kronologis, dari masa ke masa, dekade ke dekade, literatur tafsir di Malaysia terus berkembang dan mengalami dinamika yang cukup menarik. Baik dari segi penyampaian, penulisan, metode yang digunakan, dan referensi yang digunakan. Sebagaimana Alquran pada periode awalnya, geliat tradisi penafsiran Alquran di Malaysia juga bisa dipetakan jadi dua tradisi; Oral dan tulisan. Tradisi oral penafsiran Alquran adalah sebuah gejala awal yang menimbulkan banyaknya ketertarikan Muslim Malaysia kepada Alquran.

Sebuah gejala yang menimbulkan fenomena "Qur'ani", dan ditransmisikan secara oral, tentu mengharuskan sosoksosok kompeten dan pakar yang membidanginya sebagai transmitter. Seiring perkembangan dunia literasi dan semakin menguatnya fenomena ini, tradisi oral para pendakwah (da'i/preacher) Alquran pun perlahan disisipi tradisi tafsir berbasis literasi. Banyak bermunculan buku-buku tafsir yang berkontribusi kepada perkembangan penafsiran Alquran di Malaysia. Dibawah ini akan dijelaskan mengenai akar dan geliat masingmasingnya.

\section{a. Oral}

Proses penafsiran Alquran di Malaysia pada periode-periode awalnya bermula secara lisan (oral) dan non- 
formal institusional di rumah-rumah Tok Guru,[ Tokoh agama yang dipercaya mengerti dan mampu untuk mengajarkan Alquran.] Masjid-masjid, dan madrasahmadrasah melalui pengajian-pengajian agama yang diadakan di tempat-tempat tersebut. (Ismail Yusoff, Jurnal Islamiyyat, Vol. 13) dalam hal ini, da'i Alquran adalah bintang utamanya. Kepandaian murid membaca dan memahami -bahkan menghafalkan Alquran-seolah menjadi tugas dan tanggungjawab mereka. Menurut Ismail Yusoff, untuk pertama kali Alquran secara oral ini dilakukan oleh Syekh Abdul Malik bin Abdullah (1650 - 1736), atau yang juga dipanggil dengan "Tok Pulau Manis" pada abad ke17. [Ismail Yusoff, Perkembangan dan Penulisan... Hlm. 21. Lihat juga Haziyah Husein, (2016:137). Bandingkan dengan Nabir Abdullah, 1976: 9-10) Tok Pulau Manis yang saat itu dianggap sebagai tokoh yang cukup mengerti dengan Alquran mengajar dengan cara mengenalkan setiap huruf hijaiyyah, lalu dilanjutkan dengan membaca juz ke-30 (juz Amma), dan setelah itu memberikan pesan-pesan Alquran secara perlahan kepada muridnya, (Husein dan Majid, 2013 h. 1734)

Tok Pulau Manis mentransmisikan isi-isi Alquran kepada setiap orang yang datang ke rumahnya untuk belajar. (Ismail Yusoff, 22) Mustaffa Abdullah menyebutkan bahwa pada periode awal penafsiran Alquran di Malaysia ini, tidak ada tempat khusus atau lembaga resmi untuk belajar Alquran, namun setiap pelajar bisa mendatangi rumah-rumah guru jika ingin mendapatkan pelajaran seputar tafsir Alquran. (Mustaffa Abdullah, 2010:36) Maka, dapat dipahami, bahwa Alquran secara khusus, dan seluruh nilai-nilai Islam secara umum, sejak awal itu didatangi, bukan mendatangi. Sedangkan hari ini, banyak sekali -untuk tidak menyebutkan seluruhnya-ditemukan, bahwa nilainilai keislaman, bahkan Alquran, tidak lagi didatangi, tapi sudah mendatangi.
Realita ini tidak berarti bahwa proses transmisi Islam tereduksi dengan pola yang berubah. Pada banyak sisi, perubahan pola ini justru sangat efektif. Tentunya untuk menguji reliabilitas hal ini dibutuhkan riset yang lebih mendalam dan akurat. Selain itu, bahkan, dengan perubahan pola dalam konteks realitas yang terus berjalan, da'i, demi tersampaikannya setiap pesan-pesan Alquran ke setiap relung dan sendi kehidupan masyarakat, dituntut untuk lebih inovatif.

Adapun Tok Pulau manis sendiri, pada awalnya belajar tafsir, fiqh, tasawwuf, dan ilmu-ilmu keislaman lainnya di Aceh ke Syekh Abdur Rauf asSinkily (1615-1693) sebelum melanjutkan studinya ke Mekkah dan kembali ke Malaysia pada pertengahan tahun 1960. (Muhammad Abu Bakar, 1991:54) Sehingga, paparan ideologi asSinkily juga lah yang berkontribusi dalam setiap dakwah Tok Pulau Manis jika dilihat menggunakan kaca mata epistemologis. Hampir setiap da'i, dalam materi dakwahnya tidak akan jauh-jauh dari kompetensi gurunya. as-Sinkily sebagai kompeten dalam bidang tafsir Alquran --terbukti dengan karyanya; Turjuman al-Mustafid-adalah yang mempengaruhi dalam epistemologi dakwah Alquran murid-muridnya. Termasuk Tok Pulau Manis dalam setiap transmisi tafsir berbasis oralnya ini.

Selain Tok Pulau Manis di Trengganu, juga ada Tok Shihabuddin bin Zainal Abidin (1670-1770) yang mengajar Alquran dengan penafsiranpenafsirannya di daerah bagian Pahang. Tok Shihabuddin juga merupakan murid As-Sinkily dan Tok Pulau Manis di Aceh. (Rashidi Mohamed Sabri, 2004: 7) Sampai hari ini tidak ada catatan tahun berapa keberangkatan Tok Shihabuddin ini belajar ke Aceh dan kepulangannya ke Pahang, namun Haziyah Husein mencatat bahwa proses penafsiran Alquran secara oral yang dilakukan Tok Shihabuddin di 
Pahang baru dimulai pada tahun 1750 . (Haziyah Husein, 13)

Ada dua kemungkinan yang menyebabkan kenapa proses penafsiran Alquran secara oral di rumah-rumah Tok Guru cukup digandrungi oleh pelajar dan masyarakat muslim Malaysia ketika itu; pertama, belum adanya terjemahan Alquran ke bahasa Nusantara. Sehingga, Alquran yang berbahasa Arab jadi sangat sulit untuk dimengerti oleh masyarakat Malaysia yang saat-saat itu masih di bawah jajahan Portugis dan Belanda, sehingga mendatangi Tok Guru dan mendengar setiap dakwahnya di setiap kesempatan adalah satu-satunya cara untuk tetap bisa berinteraksi dengan Alquran. Kedua, kitab-kitab tafsir periode awal dan pertengahan yang sudah mulai beredar ke seluruh wilayah Nusantara, masih menggunakan bahasa daerah asalnya masing-masing. Persoalan bahasa memang selalu jadi polemik tersendiri dalam proses transmisi pesan-pesan ilahi dalam Alquran.

Geliat penafsiran Alquran secara oral oleh pendakwah di Malaysia ini baru menjadi massif setelah kepulangan beberapa putera daerahnya dari belajar di timur tengah, seperti Syekh Ahmad AlHadi (1867-1934), [Talib Samad, Syed Syeikh al-Hadi: Sasterawan Progresif Melayu (Kuala Lumpur: Dewan Bahasa dan Pustaka, 1992) hlm. 19.] Mohd Yusof Ahmad (1868-1933), Wan Ahmad bin Muhammad Zain (1850-1922), dan Musthafa al-Fatani (18561908)[ Mohammad Redzuan, Islam dan Masyarakat Melayu: Peranan dan Pengaruh Timur Tengah (Kuala Lumpur: Universitas Malaya Press, 2005) hlm. 22.] Muhammad Redzuan juga mencatat bahwa orang-orang ini selama di Timur Tengah belajar ke tokoh-tokoh tafsir asli Timur Tengah, seperti Muhammad Abduh (1849-1905), Muhammad Rasyid Ridha (1866-1935), dan Musthafa al-Maraghi (w. 1945). Dan mereka juga belajar ke tokoh-tokoh tafsir Nusantara yang memang sudah berada di sana, seperti
Muhammad Arsyad al-Banjari (17101812), Nawawi al-Bantani (1815-1879), Daud al-Fatani, dan Ahmad Khatib alMinangkabawi (1860-1916). (Mohammad Redzuan, 1737) Banyaknya pelajar Malaysia berangkat belajar ke sana menunjukkan bahwa kebutuhan akan Alquran di Malaysia semakin meningkat.

Tidak jauh berbeda dengan Indonesia, proses pentransmisian isi-isi kandungan Alquran secara oral ini juga sudah berlangsung sejak abad ke-17 itu, Muhammad Yunus menyebutkan bahwa Pendidikan Islam di Indonesia diawali dengan kegiatan yang dinamai "Pengajian Alquran" yang dilaksanakan di langgarlanggar, surau-surau, dan masjid-masjid yang ada. (Islah Gusmian, 2013)

Melihat kenyataan yang telah dipaparkan di atas, dapat diambil ikhtisar bahwa tafsir Alquran periode awal, dakwah, dan pendakwah adalah satu kesatuan yang saling berkelindan dan tidak dapat dipisahkan. Setiap pendakwah berdakwah dengan menafsirkan Alquran, dan setiap pesanpesan Alquran hanya akan tersampaikan melalui lidah para pendakwah yang sedang berdakwah.

\section{b. Institusi dan Awal Tradisi Tulis- menulis Tafsir}

Menyadari proses penafsiran Alquran secara oral di rumah-rumah Tok Guru pada abad 17 sampai awal abad 19 cukup diminati masyarakat Muslim di Malaysia, proses penafsiran Alquran mulai diinstitusikan. Tafsir Alquran menjadi satu mata pelajaran wajib pada lembaga-lembaga pendidikan resmi seperti Pondok [Pesantren] dan Madrasah. Pondok pertama yang mengajarkan tafsir adalah Pondok yang didirikan Tok Kenali pada tahun 1917. (Abdullah al-Qari, 2009: 43) Institusi ini adalah sebagai salah satu metode yang kontributif dalam dimensi oralitas dari setiap pendakwah untuk 
mentransmisikan Alquran dengan segala penafsirannya.

Pondok Tok Kenali inilah yang kemudian melahirkan tokoh-tokoh penulis tafsir di Malaysia seperti; Muhammad Idris al-Marbawi (18941990), Ali Salah al-Din (1899-1968), Haji Abdullah Tahir Haji Ahmad (1897-1961) and Sheikh Usman Jalaluddin (1867 1952).[ Haziyah Husein dan Latifah Abdul Majid, Early Development of Quranic Exegesis in Malaysia.... Hlm. 1737.] Setelah Pondok Tok Kenali, Pondokpondok lain pun mengikuti dengan menjadikan tafsir sebagai mata pelajaran wajibnya. Adapun literatur tafsir yang digunakan sebagai referensi pengajian Alquran pada pondok-pondok tersebut seperti Tafsir al-Jalalayn, karya Jalaluddin as-Suyuthi dan Jalaluddin al-Mahalli, Madarik al-Tanzil karya al-Nasafi, Tafsir al-Qur'an al-'Azim karya Ibn Kathir, Lubab al-Ta'wil fi Ma'ani al-Tanzil karya al-Khazin, Anwar al-Tanzil wa Asrar alTa'wil karya al-Baydhawi dan Tarjuman al-Mustafid, karya as-Singkily. (Abdul Hafiz, 2001 : 33)

Pada awalnya, budaya tulis-menulis tafsir di Malaysia tidak langsung dengan menulis satu kitab tafsir yang menjelaskan sebagian atau seluruh ayat Alquran, namun, dengan menerjemahkan kitab-kitab "asing" yang berdisiplin fiqh, tasawuf, aqidah, dll, terutama yang berbahasa Arab ke bahasa melayu dan menyisipkan penjelasan seputar ayat Alquran yang dikutip dalam kitab-kitab tersebut. (Yahya, Naskah Jawi, 1994:1617) cara penyisipan penafsiran ini, sudah barang tentu tidak akan jauh-jauh dari cara penafsiran Alquran berbasis oral yang sering disampaikan dalam ceramah para pendakwah. Mungkin hanya metode dan corak yang akan membedakannya. Tidak adanya dokumentasi penafsiran Alquran berbasis oral dari pendakwah Alquran periode awal itu, menjadi kesulitan tersendiri dalam mengkomparasikannya.
Adapun yang murni tafsir Alquran dalam bentuk buku tafsir Alquran di Malaysia kala itu, juga masih berupa terjemahan kitab-kitab tafsir; seperti Tafsir Jalalayn, Maraghi, Ibn Katsir, dll. Kemandekan penulisan tafsir ini bisa jadi dikarenakan kurang beraninya para guruguru dan da'i-da'i Alquran menuliskan apa yang sudah mereka ajarkan dan dakwahkan menjadi sebuah kitab tafsir. Hal ini bisa dibuktikan pada pendahuluan sebuah terjemahan Tafsir Jalalayn surat Al-Baqarah yang dilakukan oleh Syaikh Usman. Syaikh Usman dengan mengutip pendapat Imam al-Ghazali menyebutkan bahwa seseorang yang ingin menafsirkan Alquran haruslah mempunyai 15 disiplin ilmu terkait sebelum mulai menafsir. (Syaikh Usman, xxi) Kiranya perkataan alGhazali inilah yang "menghantui" para guru dan da'i Alquran di Malaysia untuk menulis kitab tafsir. Padahal, hemat penulis, dalam mendakwahkan Alquran secara oral pun, tidak akan mungkin da'i tersebut terlebih dahulu mempertimbangkan 15 aspek seperti yang disyaratkan Imam al-Ghazali itu. Dengan begitu, maka pertanyaan yang akan timbul adalah kenapa keberanian menafsirkan Alquran dalam dakwah secara oral tidak berlaku dalam tradisi tafsir berbasis tulisan?

Adapun kitab tafsir karya orang Malaysia dan berbahasa melayu berbuah dari tangan Muhammad Sa'id bin Umar yang berjudul Tafsir Nur al-Ihsan, Sa'id memulainya pada tahun 1925 dan berhasil menyelesaikannya pada tahun 1927. Tapi sayangnya, karya ini terbit untuk pertama kalinya di Mekkah sebanyak empat jilid. Sedangkan di Malaysia baru dicetak pada akhir tahun 1936.

Di samping itu, Penulisan sebuah tafsir yang "murni" ditulis oleh orang Malaysia, berbahasa melayu, dan di Malaysia baru dimulai oleh Muhammad Idris al-Marbawi (1894-1990) pada tahun 1936. Al-Marbawi menulis tiga tafsir sekaligus pada tahun yang sama, masing- 
masingnya berjudul Tafsir Surah Yasin Bahasa Melayu, Tafsir Quran Marbawi, dan Alif Lam Mim. (Mustaffa Abdullah, 2016: 37) Ibarat pembuka keran yang selama ini terkunci dan nyaris berkarat, al-Marbawi berhasil mempelopori penulisan tafsir di Malaysia. Mustaffa Abdullah yang melakukan penelitian tentang khazanah tafsir di Malaysia pada tahun 2010 berhasil mengumpulkan 20 kitab tafsir yang ditulis orang Malaysia asli dan diterbitkan dalam bentuk buku. (Mustaffa Abdullah, 2016: 177)

Berhasilnya pelacakan atas kitab tafsir awal karya Sa'id dan al-Marbawi pada tahun 1938 itu dengan sendirinya membantah tesis Peter G. Riddell yang mengatakan bahwa kitab-kitab tafsir di Malaysia baru muncul setelah selesainya perang dunia II pada bulan September tahun 1945. (Peter G. Riddell, 2001:266) Simplifikasi Riddell dalam memetakan geliat tafsir Alquran di Malaysia ini mungkin saja dengan meninggalkan peran para pendakwah yang sudah jauh lebih dahulu menafsirkan Alquran dalam dakwahnya.

\section{Keterpengaruhan Tafsir di Malaysia}

Melihat geliat penafsiran Alquran dalam dakwah oral dan tulisan di Malaysia yang cukup signifikan pada abad XX dan XXI, menarik juga untuk menelisik apa dan siapa yang mempengaruhi putera-putera tanah melayu Malaysia ini dalam menafsirkan Alquran. Melihat dari riwayat pendidikan nama-nama penggerak tafsir seperti yang disebutkan di atas, maka yang mempengaruhi penafsiran Alquran di Malaysia bisa diringkas menjadi tiga pengaruh saja; Abdurrauf as-Sinkily dengan Turjuman al-Mustafidnya, Muhammad Abduh dan Rasyid Ridha dengan majalah AlManarnya, dan Ahmad Musthafa alMaraghi dengan Tafsir al-Maraghinya. Di bawah ini akan dijelaskan apa penyebab para tokoh tafsir Malaysia terpengaruh nama-nama tersebut, dan bagaimana pengaruhnya pada proses penafsiran Alquran di Malaysia.

\section{a. Pengaruh Abdurrauf as-Sinkily}

Sebagai tafsir Alquran tertua di bumi Nusantara yang memuat lengkap $30 \mathrm{Juz}$ dan ditulis dalam bahasa Melayu, Tarjuman al-Mustafid yang ditulis oleh 'Abdurrauf bin Aly al-Fansuriyy asSinkiliy, atau yang dikenal dengan Syeikh Abdurrauf al-Sinkily tentu mempunyai pengaruh yang tidak sedikit bagi proses penafsiran Alquran di Malaysia.

Hal ini bisa dibuktikan dengan banyaknya para pionir tafsir Malaysia yang pergi belajar ke Aceh, seperti Tok Pulau Manis, Tok Shihabuddin, dan TokTok Guru lainnya. Belajar dengan AsSinkily memang hanya jadi pijakan awal mereka sebelum melanjutkan studinya ke Mekkah dan negara-negara Timur Tengah lainnya. Namun, sepulangnya dari Timur Tengah, mereka tetap menjadikan Turjuman al-Mustafid sebagai referensi utama ketika mengajar dan mendakwahkan tafsir Alquran di rumahrumah, surau-surau, atau masjid-masjid.

Terlepas dari perdebatan panjang tentang asal-usul Turjuman Al-Mustafid dan segala problem epistemologis asSinkily ketika menyusunnya, magnum opus as-Sinkily ini menjalar hampir ke seluruh ruang belajar ilmu-ilmu keislaman di Malaysia. Baik secara oral, maupun tulisan. Baik formal-intitusional, maupun non formal-institusional. Hal ini disebabkan karena Turjuman al-Mustafid saat itu, merupakan satu-satunya karya tafsir yang ditulis dalam bahasa melayu. Eksistensinya bertahan cukup lama di Malaysia, selama beberapa abad sampai kehadiran tafsir karya Muhammad Sa'id dan Idris al-Marbawi, Turjuman alMustafid masih menjadi satu-satunya tafsir rujukan para Tok Guru.[ Peter G. Riddell, Islam and the Malay-Indonesian World... hlm. 269] Hal ini mengindikasikan bahwa "berkuasanya" Turjuman al-Mustafid dalam diskursus tafsir Alquran ketika itu, menjadikan 
setiap proses pentransmisian pesanpesan ilahi dalam dakwah oleh setiap transmitter bernuansa as-Sinkily.

\section{b. Pengaruh Muhammad Abduh dan Rasyid Rida}

Gerakan Reformasi Islam di Malaysia dipimpin oleh reformis modern yang disebut dengan "Kaum Muda". Reformasi ini mempunyai dua misi utama. Pertama, membangun pendidikan publik melalui sekolah-sekolah agama modern yang dikenal dengan madrasah, dan Kedua, untuk menyerukan perubahan sosial melalui kesadaran sosial-politik terhadap kolonialisme dan pengarusutamaan "tipu daya" Barat. Ide-ide reformasi disebarkan melalui majalah dan surat kabar lokal seperti Al-Imam (1906-1908).

Di antara reformis awal Kaum Muda adalah Syed Ahmad al-Hadi (1867-1934) dan Tahir Jalaluddin (1869-1956) yang mengikuti pengembangan reformasi pendidikan Universitas AlAzhar.[ Salamon, A.S., "Reform in Islam and al-Azhar" (Kuala Lumpur: AlRahmaniah, 1988: 46-47) Mereka menjalankan misinya langsung di bawah pengaruh Al-Manar yang membawa pemikiran Muhammad Abduh dan Rasyid Ridha tentang gerakan reformasi dan kebangkitan Islam melalui sologan "kembali kepada Alquran dan Sunnah" (back to Quran and Sunnah). Mereka menguraikan ide-ide reformis dari Mesir ke Malaysia di berbagai bidang termasuk tafsir Alquran. legalitas penafsirannya dibangun melalui sologan yang diusungnya tadi. Sehingga, setiap penafsiran Alquran yang disampaikannya menjadi mudah diterima masyarakat Muslim Malaysia yang percaya dengan sologan itu. Implikasi sologan itu adalah bahwa setiap kata yang ditafsirkan pengusungnya dianggap sebagai manifestasi.

Kaum Muda ini mendirikan madrasah-madrasah di Negeri Pemukiman Selat untuk memperkenalkan sistem pendidikan yang lebih sistematis dan terintegrasi antara studi agama dan sains.

Reformasi dalam tafsir Alquran yang diprakarsai oleh Kaum Muda ini bergeser dari yang pada mulanya menggunakan metode pengajaran dan dakwah tradisional ke metode tafsir modern. Secara tradisional, mempelajari tafsir hanya didasarkan pada menghafal teks tanpa menguasai pemahaman yang jelas tentang makna ayat-ayat Alquran. Selain itu, tidak ada interaksi dua arah antara guru/da'i dan murid dalam proses belajar mengajar, pola semacam itu meniscayakan para siswa jadi tidak memiliki kesempatan untuk mengajukan pertanyaan demi menghapus ambiguitas yang ditangkapnya dalam memahami tafsir ayat-ayat Alquran dari si guru/da'i. Dan di samping itu, pola belajar seperti ini juga mencegah siswa untuk menjadi lebih responsif sehingga menumbuhkan budaya belajar yang buta dan mono. Oleh karena itu, generasi awal Kaum Muda saat itu, dalam setiap dakwah dan kesempatannya, concerned pada memperkenalkan metode memahami penafsiran ayat-ayat Alquran daripada mengadopsi metode menghafal teks. Sehingga komunikasi dua arah antara guru/da'i dengan murid di kelas, memproyeksikan siswa menjadi lebih responsif dalam proses pembelajaran mereka.

Di sisi lain, penggunaan referensi tafsir klasik seperti Tafsir Ibnu Katsir, Tafsir al-Nasafi, Tafsir al-Baidhawi dan Tafsir Jalalayn masih dipertahankan dalam studi penafsiran Alquran di Malaysia. Sedangkan Tafsir al-Manar menjadi pelopor dalam memperkenalkan metode tafsir modern yang belum pernah diajarkan sebelumnya di Malaysia. Gagasan reformis Muhammad Abduh dan Rasyid Rida secara luas juga disebarluaskan oleh para guru agama lokal yang diilhami oleh para ulama Kaum Muda melalui lembaga-lembaga madrasah tersebut. (Mustaffa Abdullah, 2009: 178-179) 


\section{c. Pengaruh al-Maraghi}

Pada awal abad ke-20, Kaum Muda, dalam setiap dakwah Alqurannya, memperkenalkan metode baru dalam mengajar tafsir dengan membuka keran ijtihad untuk para siswa, sehingga siswa bisa sedikit bebas dalam menggunakan ijtihadnya ketika menafsir Alquran. Meskipun teks-teks tafsir klasik masih digunakan di madrasah, namun metode pengajaran tafsirnya telah berubah. Setelah pendudukan Jepang di Malaysia, reformasi pengajaran tafsir pun terjadi. Tahun 1945, Tafsir al-Maraghi muncul sebagai model tafsir modern di Mesir. Popularitas Al-Maraghi juga merembes ke beberapa negara bagian Malaysia; Kelantan, Perak dan Melaka. Tafsir AlMaraghi yang menerapkan metode tafsir modern; Adabi-Ijtima'i, yang menghubungkan makna ayat-ayat Alquran dengan masalah kehidupan social-humaniora saat itu, atau juga bisa dikatakan kontekstualis bagi problema zamannya. Dengan demikian, Kaum Muda memperkenalkan dua metode dalam reformasi tafsir Alquran, yaitu menerapkan metode ijtihad dan tafsir Adabi -Ijtima'i sebagai reformasi yang telah dilaksanakan Al-Maraghi di Universitas al-Azhar. (Amiratul Munirah, 2015: 45) Al-Maraghi yang notabene adalah murid dua reformis Mesir itu melanjutkan misi kedua gurunya, Muhammad Abduh dan Rasyid Ridha dalam memimpin agenda reformasi Islam, khususnya dalam transmisi tafsiran Alquran.

Kaum Muda, melalui pengajaran Tafsir al-Maraghi di madrasah-madrasah, memperkenalkan ijtihad berdasarkan pendapat para ulama kontemporer untuk memastikan tidak adanya penyimpangan ajaran Islam dan difusi israiliyyat ke tengah-tengah para pelajar Malaysia. Ijtihad ditekankan dengan menghadirkan pandangan-pandangan yang disimpulkan dari berbagai mazhab untuk mengumpulkan berbagai pandangan yang berdasarkan argumen naqli. Kesadaran untuk menggunakan ijtihad dalam tafsir Alquran sangat menarik antusiasme para pelajar Alquran di lembaga-lembaga pendidikan Islam Malaysia, terutama madrasah. Awalnya, para guru dan da'i pengajar tafsir alumnus Aceh dan Mekkah itu mengajar dengan sistem pendidikan tradisional yang menggunakan metode deskripsi isi buku tafsir dari sampul ke sampul, lembar ke lembar tanpa banyak elaborasi dan perluasan makna menuju permasalahan social-humaniora masyarakat yang terjadi. Mereka menekankan pada tata bahasa dan bacaan yang tepat tanpa menjelaskan analisis tafsir yang mencakup aspekaspek permasalahan kontemporer; politik, ekonomi dan sosial. Karenanya, Ijtihad jadi tidak dipraktikkan untuk memahami dan menganalisis isi buku-buku tafsir, dan mereka hanya mengandalkan apa yang telah tertera dalam tafsir rujukannya. Sebagian besar guru tafsir ini menggunakan Tafsir Jalalayn. (Amiratul Munirah Yahaya dan Mustaffa Abdullah, 46) Sementara para guru madrasah dan da'i alumnus Mesir dan India, mampu menggambarkan interpretasi ayat-ayat Alquran secara lebih mendalam dengan Al-Maraghi sebagai pegangannya. Spirit reformasi yang diwarisi Muhammad Abduh, Rasyid Ridha, dan Al-Maraghi juga mempengaruhi perubahan pola transmisi isi kandungan Alquran oleh para guru dan da'i.

\section{KESIMPULAN}

Tafsir Alquran di Malaysia mempunyai perjalanan dan problematika yang unik dan cukup menarik di Nusantara. Sebagai negara yang mempunyai penduduk muslim cukup banyak, Malaysia dalam bidang quranic studies dan tafsir memang agak sedikit terlambat jika dibandingkan dengan Indonesia, namun geliatnya membuktikan bahwa Malaysia, dengan modal para da'i alumnus Aceh, Mesir, dan India itu juga punya minat quranic studies dan tafsir yang tinggi. 
Keterlambatannya juga tak lepas dari pengaruh kolonialisme bangsa-bangsa Eropa ke Asia Tenggara. Kolonialisme yang cenderung kejam kepada pendakwah, menyebabkan keterlambatan yang cukup signifikan.

Pada prosesnya, penafsiran Alquran di Malaysia bisa dibagi jadi tiga fase; pertama, pengajian Alquran di rumahrumah Tok Guru. Pada fase ini, Para Tok Guru yang sudah belajar ke Aceh dan Timur Tengah mengajar setiap siswa yang datang ke rumahnya untuk membaca dan memahami Alquran. Kedua, institusional tafsir melalui sekolahsekolah dan universitas yang mengajarkan studi Islam. Ketiga, penulisan. Dalam perjalanannya, penulisan tafsir diawali dengan menerjemah karya-karya Timur Tengah oleh para sarjana yang sudah memiliki kemampuan berbahsa Arab. Sedangkan penulisan tafsir yang "murni" hasil ijtihad para sarjana Muslim Malaysia baru dipelopori oleh Muhammad Sa'id dengan Tafsir Nur al-Ihsannya, dan Idris alMarbawi dengan Tafsir al-Marbawinya.

Semua geliat pertumbuhan tafsir Alquran di Malaysia dari periode awal sampai dewasa ini, adalah peran penting para penggiat Alquran yang memainkan peran dakwah dalam setiap dakwahnya. Beberapa aktor seperti Tok Pulau Manis, Tok Shihabuddin, dan lain-lain tercatat sebagai pionirnya.

Dilihat menggunakan kaca mata hermeneutika filosofis Alquran (Quranic philosophische hermeneutics) perkembangan tafsir-tafsir Alquran di Malaysia ini pada setiap cara dan tingkatannya, juga tak lepas dari pengaruh-pengaruh tokoh-tokoh tafsir trans nasional. Secara garis besar, keterpengaruhan dan semua efek yang ditimbulkannya muncul dari Abdurrauf As-Sinkily, Muhammad Abduh dan Rasyid Ridha, dan al-Maraghi.

\section{DAFTAR KEPUSTAKAAN}

A.S., Salamon. 1988. Reform in Islam and Al-Azhar. Kuala Lumpur: alRahmaniah.

Abdullah, Amiratul Munirah \& Mustaffa. 2015. "The influence of Shaykh Ahmad Mustafa al-Maraghi's Thoughts in Quranic exegesis in Malaysia." Research in Islamic Studies 45.

Abdullah, Mustaffa. 2010. Khazanah Tafsir di Malaysia. Kuala Lumpur: Academy of Islamic Studies University Malaysia.

—. 2009. Rasyid Ridha dan Pengaruhnya di Malaysia. Kuala Lumpur: Universitas Malaysia Press.

Abdullah, Nabir. 1976. Maahad II Ihya Assyarif Gunung Semanggol 19341959. Kuala Lumpur: Departemen of History University Kebangsaan Malaysia.

Asari, Amirullah Sain. 2016. "History and Development of Tafsir in Southeast Asia." Waratsah 177.

Bakar, Muhammad Abu. 1991. Ulama Trengganu: Suatu Sorotan. Kuala Lumpur: Utusan Press.

Gusmian, Islah. 2013. Khazanah Tafsir di Indonesia: dari Hermeneutika hingga Ideologi. Yogyakarta: LKiS.

Hafiz, Abdul. 2001. Pengajian Tafsir di Pondok-Pondok Negeri Kelantan. Kuala Lumpur: Universitas Kebangsaan Malaysia.

Husein, Haziyah. 2016. "The Emergence of Quranic Exegesis in Malaysia." In The Quran in Malay-Indonesian World, by Andrew Rippin, edited by Andrew Rippin, 137. New York: Routledge.

Qori, Abdullah. 2009. Tuk Kenali Penggerak Ummah. Kuala Lumpur: Dewan Bahasa dan Pustaka.

Redzuan, Mohammad. 2005. Islam dan Masyarakat Melayu: Peranan dan Pengaruh Timur Tengah. Kuala Lumpur: Universitas Malaya Press.

Riddell, Peter G. 2001. Islam and the Malay-Indonesian World: 
Transmission and Responses. Singapura: Horizon Books.

Sabri, Rashidi Mohamed. 2004. Kajian Pengajian Tafsir Alquran di Negeri Pahang 1909-2004. Kuala Lumpur: Universitas Kebangsaan Malaysia.

Samad, Talib. 1992. Syed Syeikh Al-Hadi: Sasterawan Progresif Melayu. Kuala Lumpur: Dewan Bahasa dan Pustaka.

Smith, Huston. 2001. Agama-Agama Manusia. Translated by Safroedin Bahar. Jakarta: Yayasan Obor Indonesia.

Smith, Wilfred C. 2005. Kitab Suci AgamaAgama. Translated by Dedi Iswadi. Bandung: Teraju.

Usman, Syekh. 1936. Anwar al-Huda wa Amtar al-Nada. Kuala Lumpur: Berita Publishing.

Yahya, Mahyuddin. 1994. Naskah Jawi: Sejarah dan Teks. Kuala Lumpur: Dewan Bahasa dan Pustaka \& Kementrian Pendidikan Malaysia.

Yunus, Muhammad. 1984. Pendidikan Islam di Indonesia. Jakarta: HIdakarya Agung.

Yusoff, Ismail. -. "Perkembangan dan Penulisan Kitab-Kitab Tafsir di Malaysia." Islamiyyat 19. 